\title{
Occurence of ecto- and endo parasites in pigeon (Columba livia Linn.)
}

\author{
Sharmin Musa, Sharmin Dil Afroz and Hamida Khanum \\ Department of Zoology, University of Dhaka, Dhaka-1000, Bangladesh
}

Pigeons (Order Columbiformes) are ubiquitous birds and can be found in virtually every town and city around the globe (Marques et al. 2007). Pigeons are related to human since ancient time (BC. 3000-5000). They live side by side with human as a source of food, hobby and experimental purposes (Sari et al. 2008). Several health problems can affect pigeons but parasite infections play a major role. They constitute a major source of infection and transmission of diseases (Marques et al. 2007) The effects of parasitism on birds are often severe, including retarded growth, low egg production and susceptibility to other infections (Dranzoa, 1999). Substantial work has been done on parasitic infections of poultry in Uganda and has found that Trichomonas gallinarumv and helminth parasites occur in domestic pigeon (Dranzoa, 1999). Sendagire (1996) studied the prevalence, and Barasa (1996) worked on the histopathological lesions of intestinal and caecal coccidiosis in and around Kampala, Uganda. Domestic pigeons (Columba columba) are among poultry species kept in the Tanzania. Like other domestic poultry these are also part of subsistence farming done by most poor families in Tanzania. A study was carried out to observe the occurrence of parasites (endoparasites, ectoparasites and blood) of pigeons in Morogoro municipality of Tanzania (Msoffe et al. 2010). Another study was performed in Turkey to determine the prevalence of possible parasites in the faecal samples of the domestic and wild pigeons in the Nigde region and to obtain information about the effects of some factors such as season and gender on parasitic infections (Sari et al. 2008).

There are not much published works on parasites of pigeons in Bangladesh. Begum and Shaikh (1987) and Nasrin (2004) recorded parasites of pigeon. Pigeons often harbour zoonotic parasites (Cooper, 1997) and some of these are often transmissible to humans (Cooper 1990). Another reason for studying the parasites of domestic pigeons is because they are widespread and might transmit their parasites to wild birds (Dranzoa, 1999). The present study was therefore designed to determine the intensity of ecto and endo parasites of domestic pigeons (Columba livia
Linn.). The objectives of the study were (1) Identification of ecto and endo parasites of Columba livia, (2) distribution of parasite in the gut of host, (3) incidence and intensity of infestation of ectoparsites (4) incidence and intensity of infestation of endo parasites.

Total of 24 pigeon were brought to Parasitology Laboratory, Department of Zoology, University of Dhaka. The length (beak end to tail end) of the individual pigeons were taken in centimeters $(\mathrm{cm})$. The pigeons were grouped into 3 length groups (1) $19-22 \mathrm{~cm}$, (2) $23-26 \mathrm{~cm}$ and (3) $27-30 \mathrm{~cm}$. The sexes of the pigeons were identified after dissection of reproductive organs. For collection of ecto parasites, aerosol $(\mathrm{ACl})$ was sprayed over the feathers of the body and left for five minutes. After shaking the pigeon, parasites were collected and preserved in $70 \%$ alcohol, cleared in lactophenol and mounted in canada balsm in a slide. For collection of endo parasites, the alimentary tract was separated out and then differentiated into oesophagus, crop, proventriculus, gizard, duodenum, small intestine, caecum and rectum. The separated parts were then put in different petridishes with normal saline $(0.9 \% \mathrm{Nacl}$ Soln) and organs were opened by incision. A binocular dissecting microscope was used to identify the parasites.Trematodes and cestodes were fixed in Acetic Formal Alcohol (AFA) and for both groups cleared in lactophenol and stained in borax carmine (diluted with lactophenol). Dehydration was done by a upgrading of ethanol. Collected parasites were identified according to the figure and description given by Yamaguti (1958, 1959, 1961), Soulsby (1969), Cheng (1985) and Khanum (1974).

Total 24 pigeons were examined to determine the rate of infestation of ecto and endo parasite in Columba livia, $22(91.67 \%)$ of them were infected with five species of mallophagan bird lice. Total 482 parasites were collected,. Columbicola columbae $(50 \%)$ showed highest prevalence while Menacanthus starmineus had highest intensity (20.25 \pm 3.5$)$ (Table 1). 5 species of mallophagan ectoparasites was found of which Columbicola columbae had highest prevalence, among others Menopon gallinae, Menacanthus stramineus, Colpocephalum turbinatum, Columbicola columbae , Lipeurus caponis. 
Table No.1 Incidence and intensity of ectoparasites in Columba livia

\begin{tabular}{lccccc}
\hline Name of ecto parasites & $\begin{array}{c}\text { No.of host } \\
\text { examined }\end{array}$ & $\begin{array}{c}\text { No. of host } \\
\text { infected }\end{array}$ & $\begin{array}{c}\text { Incidence } \\
(\%)\end{array}$ & $\begin{array}{c}\text { Total no of } \\
\text { parasites }\end{array}$ & Intensity $( \pm)$ \\
\hline Menopone gallinae & 24 & 4 & 16.66 & 36 & $9.00 \pm 3.00$ \\
Menacanthus starmineus & 24 & 8 & 33.33 & 162 & $20.25 \pm 3.50$ \\
Colpocephalum turbinatum & 24 & 8 & 33.33 & 74 & $9.25 \pm 3.50$ \\
Columbicola columbae & 24 & 12 & 50 & 153 & $12.75 \pm 3.00$ \\
Lipeurus caponis & 24 & 6 & 25 & 57 & $9.5 \pm 2.00$ \\
\hline
\end{tabular}

Dranzoa et al. (1999) and Foronda et al. (2004) also found $94.1 \%$ prevalnce and $100 \%$ prevalence of Columbicola columbae in Uganda and Tneriffe respectively. Menacanthus stramineus and Menopon gallinae was also found in the work of Dranzoa et. al. (1999). Lice of poultry suck blood of host and cause ill health which adversely effect economic production of poultry. Lice infestation causes weight loss at the rate of about $711 \mathrm{gms}$ per birds and decrease the egg yield at the rate of about 66 egg per bird / year and lameness is associated with heavy lice infestation (Khan et al.2003).

In the present observation, only one species of trematode was found (Echinostoma revolutum) and the prevalence was $25 \%$ and intensity of parasites $5.33 \pm 2$. Among the two cestodes, Raillietina echinobothridia had higher prevalence $(50 \%)$ and intensity $(16.08 \pm 5.5)$ while Cotugnia cuneata had lowest prevalence and intensity $(25 \%$ and $9.5 \pm 3$ ). Ecto parasites C. columbae, $M$. gallinae, and $M$. stramineus were only the found in smallest length group $(27-30 \mathrm{~cm})$ of pigeons. Almost all the species of ecto parasites except Menopon gallinae were found in the largest lenght group $(27-30 \mathrm{~cm})$. No endo-parasites were found in the smallest length group. The only trematode parasite $E$. revolutum was not found in the intermediate lenght group. The two cestode species C. cuneata and Rallietina echinobothrida were found in the largest length group (Table 2).

In the present study Raillietina echinobothridia showed highest prevalence $(50 \%)$ which is consistence with the study of Foronda et.al. (2004), Mushi et al. (2004) and Msoffe et.al. (2010) where they found $44 \%, 80 \%$ and $63 \%$ prevalence of Raillietina echinobothridia respectively. In a study of Dranzoa et.al. (1999) cestodes were the only helminths that were found in Columba livia. In poultry, cestode infestation is more of a problem when birds are in free-range. It is possible that transmission or infestation of parasites among pigeons occurs via contamination of feed and water.

Table 2. Incidence and intensity of endoparasites in Columba livia

\begin{tabular}{lccccc}
\hline Name of endo parasites & $\begin{array}{c}\text { No. of host } \\
\text { examined }\end{array}$ & $\begin{array}{c}\text { No.of host } \\
\text { Infected }\end{array}$ & $\begin{array}{c}\text { Incidence } \\
(\%)\end{array}$ & $\begin{array}{c}\text { Total no. } \\
\text { of parasite }\end{array}$ & Intensity $( \pm)$ \\
\hline Echinostoma revolutum (Trematode) & 24 & 6 & 25 & 32 & $5.33 \pm 2.00$ \\
Raillietina echinobothrida (Cestode) & 24 & 12 & 50 & 193 & $16.08 \pm 5.50$ \\
Cotugnia cuneata (Cestode) & 24 & 6 & 25 & 57 & $9.50 \pm 3.00$ \\
\hline
\end{tabular}

In the present investigation, trematode parasite Echinostoma revolutum had $25 \%$ prevalence. Trematode utilise snail as their intermediate host. There is less chance for pigeons to come in contact with water body to ingest snails. In Bangladesh, some work has been done on helminth infestation in domestic fowl where they found trematode, cestodesand nematode parasites Akhtar (1987) and Khanum (1997) in doemstic fowl. Domestic pigeon and fowl eat the same kind of food like grains and seeds. In the present observation, larger size pigeons had higher intensity and prevalence of parasites. Begum et. al. (2008) in their study found that Trichomonas gallinae infection was higher in older aged pigeons. Similarly, Msoffe et.al. (2010) reported higher prevalence of gastointestinal helminths in adult birds than in nestlings. Nasrin (2004) also recorded higher prevalence of parasitic infection in older birds.

Local chicken, ducks and pigeon are reared in semi-scavenging or scavenging system in our country. Such birds are in constant contact with soil (Islam et al.2009), which serves as an important reservoir and transmission media for soil transmitted helminthes (STH) and insects (Islam et. al. 2009). For this reason, all free-range managed local birds are more susceptible to helminthiasis compared to commercially reared birds. Especially in free-range birds parasitic infestations are often neglected though they are causing reduced growth and higher mortality (Islam et al., 2009). 


\section{References}

Akhtar, H 1987. Gastrointestinal nematodes from domestic fowl. Bangladesh. J. Zool. 15(2): 155-159.

Barasha, P. 1996. Gross histopathological lesions of intestinal ans caecal coccidiosis in chickens in and around Kampala. Special research project report for partial fullfilment of the requirements for award of a bachelor of Veterinary Medicine degree of Makerere University, Kampala.

Begum, N.J. \& Shaikh, H. 1987. Prevalence of helminth parasites of pigeons (Columba livia), Bangladesh, Vet. J. 21(3-4): 89-93.

Begum, N., Mamun, M.A.A., Rahman, S.A. \& Bari, A.S.M. 2008. Epidemiology and pathology of Trichomonas gallinae in the common pigeon (Columba livia). J. Bangladesh Agril. Univ. 6(2): 301-306.

Cheng, T.C 1964. The biology of animal parasites. W.B. Sounders company. pp.654.

Cooper, J.E. 1997. Possible hazards from birds in the rural environment. Trans. Royal. Soc. Trop. Med. Hyg 91: 366-367.

Cooper, J.E. 1990. Birds \& zoonoses. Ibis, 132: 181-191

Dranzoa, C., Ocaido, M \& Katete, P. 1999. The ecto-, gastro-intestinal and haemo parasites of live pigeons (Columba livia) in Kampala, Uganda. Avian Pathology. 28: 119-124.

Foronda, P., Rivera-Medina, J.A, Fiqueruela, E., Abreu, N. \& Casonova, J.C. 2004. Parasites of Columba livia (Aves: Columbiformes) in Tenerife (Canary Islands) and their role in the conservation biology of the laurel pigeons. Parasite. 11(3): 311-116.

Islam, A., Trisha, A.A., Das, M., \& Amin, M.R. 2009. Retrospective study of some poultry diseases at Gaibandha district in Bangladesh. Bang. J.Vet.Med. 7(1): 239-247.

Khan, M.N., Nadeem, M., Iqbal, Z., Sajid, M.S.\& Abbas, R.Z. 2003. Lice infestation in poultry. Int. Journal. Agri. Biology. 5(2): 213-216.

Khanum, H. 1974. Studies on some helminthes of some domestic fowl of Dhaka city. M.Sc. Thesis, Department of Zoology, University of Dhaka, Dhaka. pp. 163.

Khanum, H 1997. Trematode parasite Paraphostomum humairum from doemstic fowl of Bangladesh. Journal of Bengal Natural History Society. New Series, 16(2): 35-38.
Marques, S.M., Quadros, R.M, Da-Silva, C.J. \& Baldo, M. 2007. Parasites of pigeons (Columba livia) in urban areas of langes, Southern Brazil. Parasitol Latinoam. 62: 183-187.

Msoffe, P.L.M., Muhairwa, A.P., Chiwanga, G.H, Kassuku, A.A. 2010. A study of ecto- and endo parasites of domestic pigeons in Morogoro Municipality, Tanzania. African Journal of Agricultural Research. 5(3): 264-267.

Mushi, E.Z., Binta, M.G., Chabo, R.G., Ndebele, R. \& Panjirah, R. 2000. Parasites of domesticated pigeons (Columba livia domestica) in Sebele, Gaborone, Botswana. J. S. Afr. Vet. Assoc. 71(4): 249-250.

Nasrin, M. 2004. Parasites of pigeon (Columba livia) in Mymensingh District, Bangladesh. MS Thesis, Department of Parasitology, Bangladesh Agricultural University, Mymensingh.

Sari, B., Karatepe, B., Karatepe, M. \& Kara, M. 2008. Parasites of domestic pigeon (Columba livia domestica) and wild (Columba livia livia) pigeons in Niğde, Turkey. Bull Vet Inst Pulawy. 52: 551-554.

Sendagire, D. 1996. Prevalence of coccidiosis in free range and intensively managed chickens in Kampala. Special research project report for partial fulfillment of the requirements for award of a Bachelor of Veterinary Medicine degree, Makerere University, Kampala.

Soulsby, E.J.L. 1968. Helminths, Arthropods and Protozoan of Domesticated Animals. $7^{\text {th }}$ edition. Bailliere Tindall, London. pp. 809.

Yamaguti, S 1958. Systema Helminthum.Vol I. The Digenetic Trematodes of Vertebrates. Interscience Publishers Inc. New York, USA. pp. 979.

Yamaguti, S. 1959. Systema Helminthum. Vol II. The Cestodes of Vertebrates. Interscience Publishers Inc.New York, USA. pp. 1575.

Yamaguti, S 1961. Systema Helminthum.Vol III The Nematodes of Vertebrates. Interscience Publishers Inc. New York, USA. pp.679.

Zwart, P. 1993. Columbiform Medicine. In: Zoo and World Animal Medicine: Current Therapy 3. Fowler, M.E. eds. Saunders Company. pp. 240-244. 